\title{
Inovasi Infusa Kulit Kayu Akway pada Performa Ayam Broiler Umur 3 sampai 4 Minggu di Kampung Warmomi Distrik Manokwari Selatan
}

\author{
Sritiasni $^{1 *}$, Petrus Dominikus Sadsoeitoeboen ${ }^{1}$, Muhammad Agung Purnomo ${ }^{1}$, Nurtania \\ Sudarmi $^{1}$ \\ ${ }^{1}$ Program Studi Penyuluhan Peternakan dan Kesejahteraan Hewan, Politeknik Pembangunan \\ Pertanian Manokwari \\ *Corresponding author: Tiassritiasni@yahoo.com
}

\begin{abstract}
Abstrak
Penelitian ini bertujuan untuk mengetahui pengaruh pemberian infusa kulit kayu akway terhadap performa ayam broiler dengan dosis yang berbeda di kampung Warmomi distrik Manokwari Selatan kabupaten Manokwari. Penelitian ini menggunakan metode eksperimental dengan menggunakan Rancangan Acak Kelompok (RAK) dengan 3 perlakuan dan 4 ulangan, menggunakan 60 ekor DOC ayam broiler dengan jenis kelamin yang berbeda yaitu 30 ekor jantan dan 30 ekor betina. Perlakuan dalam penelitian ini terdiri dari P0 air minum tanpa kulit kayu akway, P1 air minum $1000 \mathrm{ml}+3$ gram kulit kayu akway ( 3 gr/liter) dan P2 air minum sebanyak $1000 \mathrm{ml}+5$ gram kulit kayu akway ( 5 gr/liter). Peubah yang diamati yaitu konsumsi pakan, konsumsi minum, bobot badan akhir dan konversi pakan. Metode analisis data menggunakan Analysis Of Variance (ANOVA), bila terdapat perbedaan maka diuji lanjut menggunakan metode Duncan's Multiple Range Test (DMRT). Hasil penelitian menunjukkan bahwa pemberian infusa pada air minum tidak berpengaruh nyata $(\mathrm{P}>0,05)$ terhadap konsumsi pakan, konversi dan pakan, bobot badan akhir konsumsi minum. Berdasarkan hasil penelitian dapat disimpulkan bahwa pemberian infusa kulit kayu akway dengan dosis berbeda tidak berpengaruh nyata pada performa ayam broiler pada variabel konsumsi pakan, konversi pakan, bobot badan akhir dan konsumsi minum.
\end{abstract}

Kata kunci: Ayam broiler, Kayu akway, Infusa, Penyuluhan, Peternak

\section{Abstract}

This study aims to determine the effect of infusion of Akway bark on the performance of broiler chickens with different doses in Kampung Warmomi, South Manokwari District, Manokwari Regency. This study used an experimental method using a randomized block design (RBD) with 3 treatments and 4 replications, using 60 DOC broiler chickens with different sexes, namely 30 males and 30 females. The treatment in this study consisted of PO drinking water without akway bark, P1 $1000 \mathrm{ml}$ drinking water +3 grams of akway bark (3 gr / liter) and P2 drinking water as much as $1000 \mathrm{ml}+5$ grams of akway bark (5 gr / liter). The observed variables were feed consumption, drinking consumption, final body weight and feed conversion. Data analysis method uses Analysis Of Variance (ANOVA), if there is a difference then it is further tested using the Duncan's Multiple Range Test (DMRT) method. The results showed that giving infusion in drinking water had no significant effect $(P>0.05)$ on feed consumption, conversion and feed, final body weight of drinking consumption. Based on the results of this study concluded that the administration of akway bark infusion with different doses did not significantly affect the performance of broiler chickens on variable feed consumption, feed conversion, final body weight and drinking consumption.

Keywords: Akway wood, Breeder, Broiler chicken, Extension, Infusion 
Prosiding Seminar Nasional Pembangunan dan Pendidikan Vokasi Pertanian

Politeknik Pembangunan Pertanian Manokwari, 31 Juli 2021

e ISSN : 2774-1982

DOI : https://doi.org/10.47687/snppvp.v2i1.193

\section{PENDAHULUAN}

Kayu akway merupakan tumbuhan obat yang banyak digunakan oleh masyarakat suku Arfak di Papua Barat. Tumbuhan ini tumbuh di Pegunungan Arfak Papua Barat pada ketinggian 1200-2400 meter dari permukaan laut. Tumbuhan ini digunakan oleh penduduk asli Pegunungan Arfak untuk mengobati malaria dan untuk meningkatkan vitalitas tubuh (Syakir et al., 2011).

Cepeda et al. (2018) menjelaskan bahwa senyawa fitokimia penyusun akway yaitu etanol dan etilasetat kulit kayu akway mengandung flavonoid, terpenoid, tanin, saponin, dan alkaloid, ekstrak kulit kayu akway memiliki potensi sebagai sumber antioksidan alami karena senyawa-senyawa yang terkandung di dalamnya dilaporkan memiliki aktivitas antioksidan yang kuat. sehingga dapat digunakan sebagai sumber antioksidan alami yang setara dengan vitamin $\mathrm{C}$.

Infusa adalah sediaan cair yang dibuat dengan cara mengekstraksi simplisia nabati dengan air pada suhu $90^{\circ} \mathrm{C}$ selama 15 menit. Pembuatan infusa merupakan cara paling sederhana untuk membuat sediaan herbal dari bahan lunak seperti daun dan bunga. Dapat diminum panas atau dingin (BPOM RI, 2011). Lebih lanjut dijelaskan bahwa infusa juga dipilih karena cara pembuatannya mendekati cara pembuatan resep pada obat tradisional yang telah lama digunakan oleh masyarakat (Dalimartha, 2014).

\section{METODE}

Penelitian di laksanakan selama 2 bulan dimulai dari bulan Maret sampai dengan Juni 2020. Tahap pertama pelaksanaan kajian materi dan kajian pustaka di lokasi penelitian Kampus Politeknik Pembangunan Pertanian Kabupaten Manokwari, tahap kedua pelaksanaan penyuluhan dilaksanakan di Kampung Warmomi Distrik Manokwari Selatan Kabupaten Manokwari.

Alat yang digunakan adalah 1) kandang kelompok, 2) tempat pakan, 3) tempat minum, 4) lampu bohlam, 5) tirai penutup kandang, 6) hand sprayer, 7) timbangan digital, 8) blender penggiling, 9) pengayak, 10) termohigrometer, 11) pisau, 12) gunting, 13) kain flanel, 14) gelas ukur, 15) pengaduk, 16) kompor dan panci untuk pembuatan infusa.

Bahan yang digunakan adalah kulit kayu akway, 60 ekor DOC (day old chick) ayam broiler strain CP 707 terdiri dari 30 ekor jantan dan 30 ekor betina, pakan konsentrat CP521, air bersih, desinfektan, sekapan kayu (litter), minyak tanah, dan listrik. 
Prosiding Seminar Nasional Pembangunan dan Pendidikan Vokasi Pertanian

Politeknik Pembangunan Pertanian Manokwari, 31 Juli 2021

e ISSN : 2774-1982

DOI : https://doi.org/10.47687/snppvp.v2i1.193

\section{Pembuatan Infusa Kulit Kayu Akway}

Cara pembuatan infusa kulit kayu akway adalah sebagai berikut:

1. Siapkan alat dan bahan yang akan digunakan.

2. Keringkan kulit kayu akway dengan cara dijemur dibawah sinar matahari tidak langsung atau dapat menggunakan oven hingga bahan benar-benar kering.

3. Blender kulit kayu akway hingga halus kemudian di ayak.

4. jumlah konsentrasi simplisia ditimbang sesuai dengan jumlah perlakuan ditambah air suling sebanyak $1000 \mathrm{ml}$ air yang dimasukkan dalam panci untuk membuat infusa. Kemudian dilakukan pemanasan di atas penangas air menggunakan panci infusa dengan waktu 15 menit terhitung suhu mencapai $90^{\circ} \mathrm{C}$, sambil sesekali diaduk.

5. Setelah itu diserkai dalam keadaan panas-panas menggunakan kain flanel hingga didapat volume $1000 \mathrm{ml}$, bila jumlah belum tercapai dilakukan penambahan air panas pada ampas lalu diserkai hingga didapat volume $1000 \mathrm{ml}$ (Fati, et al. 2019).

\section{Metode Penelitian}

Metode yang digunakan dalam penelitian ini adalah metode eksperimental menggunakan Rancangan Acak Kelompok (RAK). Terdiri dari 3 (tiga) perlakuan dan 4 (empat) ulangan. Sehingga terdapat 12 unit percobaan setiap unit terdiri dari 5 ekor ayam dengan umur 3 minggu. Pengelompokan dilakukan berdasarkan jenis kelamin yaitu jantan dan betina dengan perlakuan yang terdiri dari:

1. Perlakuan (P0) : air minum tanpa infusa kulit kayu akway.

2. Perlakuan (P1) : 3 gr kulit kayu akway dalam 1 liter air minum.

3. Perlakuan (P2) : 5 gr kulit kayu akway dalam 1 liter air minum.

\section{Variabel Pengukuran}

Variabel penelitian yang diukur atau diamati selama pelaksanaan penelitian adalah sebagai berikut:

\section{Konsumsi Pakan}

Saputra et al., (2013) menyatakan bahwa konsumsi ransum dapat dihitung dengan menimbang pakan yang diberikan dan sisa pakan setiap hari.

$$
\begin{gathered}
\text { Konsumsi } \\
\text { pakan }(\mathrm{g} / \mathrm{ekor})
\end{gathered}=\frac{\begin{array}{c}
\text { Pakan yang diberikan } \\
(\mathrm{g})-\text { Sisa pakan }(\mathrm{g})
\end{array}}{\text { Jumlah ayam (ekor) }}
$$

\section{Konsumsi Air Minum}

Rasyaf (2008) menyatakan bahwa konsumsi air kumulatif dapat diukur dengan cara menghitung jumlah air yang diberikan dikurangi sisa air yang dikonsumsi. 
Prosiding Seminar Nasional Pembangunan dan Pendidikan Vokasi Pertanian

Politeknik Pembangunan Pertanian Manokwari, 31 Juli 2021

e ISSN : 2774-1982

DOI : https://doi.org/10.47687/snppvp.v2i1.193

\section{Bobot Badan Akhir}

Pengukuran bobot badan akhir ayam broiler dapat dilakukan pada akhir penelitian dengan menimbang bobot badan pada masing-masing kelompok dengan umur 28 hari (4 minggu).

\section{Konversi Pakan}

Saputra et al., (2013) menyatakan bahwa konversi pakan adalah sebagai perbandingan jumlah pakan yang dikonsumsi dengan pertambahan bobot badan yang diperoleh. Untuk mengetahui konversi pakan digunakan rumus sebagai berikut:

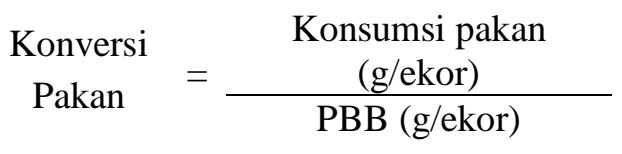

\section{Analisis Data}

Data yang telah dikumpulkan dianalisis menggunakan Analysis of Variance (ANOVA),sesuai dengan metode Rancangan Acak Kelompok (RAK) dengan menggunakan program Microsoft Excel, apabila ada perbedaan nyata di lanjutkan menggunakan uji DMRT (Duncan Multiple Range Test).

\section{HASIL DAN PEMBAHASAN}

\section{Konsumsi Pakan}

Hasil analisis data konsumsi pakan menunjukkan bahwa perlakuan pemberian infusa kulit kayu akway tidak berpengaruh nyata $(\mathrm{P}>0,05)$ terhadap konsumsi pakan pada ayam broiler jantan dan betina. Rata-rata konsumsi pakan pada ayam broiler jantan dan betina selama pemeliharaan dapat dilihat pada Tabel 1.

Tabel 1. Rataan konsumsi pakan ayam broiler jantan dan betina

\begin{tabular}{lccc}
\hline \multirow{2}{*}{ Kelompok } & \multicolumn{3}{c}{ Perlakuan } \\
\cline { 2 - 4 } & P0 (gr) & P1 (gr) & P2 (gr) \\
\hline Jantan & $1.656,50$ & $1.622,70$ & $1.514,00$ \\
Betina & $1.563,30$ & $1.787,37$ & $1.387,30$ \\
\hline
\end{tabular}

Berdasarkan Table 1 menunjukkan bahwa konsumsi pakan tertinggi pada ayam broiler jantan diperoleh pada P0 sebanyak 1.656,50 kemudian di ikuti berturut-turut P1 (3 gr/liter) sebanyak 1.622,70 dan P2 (5 gr/liter) sebanyak 1.514,00. Kemudian pada ayam broiler betina konsumsi pakan tertinggi terdapat pada P1 (3 gr/liter) sebanyak 1.787,37 dan di ikuti berturut-turut P0 (perlakuan kontrol) sebanyak 1563,30 dan P2 (5 gr/liter) sebanyak 1387,30. 
Prosiding Seminar Nasional Pembangunan dan Pendidikan Vokasi Pertanian

Politeknik Pembangunan Pertanian Manokwari, 31 Juli 2021

e ISSN : 2774-1982

DOI : https://doi.org/10.47687/snppvp.v2i1.193

Konsumsi pakan rendah disebabkan oleh suhu yang tinggi selama masa pemeliharaan yaitu suhu lingkungan mencapai $34,8^{\circ} \mathrm{C}$ dengan kelembaban $68 \%$. Keadaan seperti ini dapat menyebabkan stres panas pada ayam sehingga konsumsi pakan menurun. Qurniawan et al., (2016) menyatakan bahwa suhu lingkungan yang melebihi tingkat kenyamanan ayam pedaging berdampak pada penurunan konsumsi pakan, bobot badan dan proses metabolisme, sehingga menyebabkan performa yang kurang baik dan tidak menguntungkan.

\section{Konsumsi Air Minum}

Rataan asil analisis data konsumsi air minum pada ayam broiler jantan dan betina selama pemeliharaan dapat dilihat pada Tabel 2.

Tabel 2. Rataan konsumsi air minum ayam broiler jantan dan betina.

\begin{tabular}{llll}
\hline \multirow{2}{*}{ Kelompok } & \multicolumn{3}{c}{ Perlakuan } \\
\cline { 2 - 4 } & P0 $(\mathbf{m l})$ & P1 $(\mathbf{m l})$ & P2 $(\mathbf{m l})$ \\
\hline Jantan & $2.481,00$ & $1.757,00$ & $2.204,00$ \\
Betina & $2.167,00$ & $2.158,75$ & $2.151,00$ \\
\hline
\end{tabular}

Berdasarkan tabel hasil analisis di atas dapat dijelaskan bahwa perlakuan infusa kulit kayu akway terhadap konsumsi air minum ayam broiler jantan dan betina tidak berpengaruh nyata $(\mathrm{P}>0,05)$. Konsumsi air minum tertinggi pada ayam broiler jantan diperoleh pada P0 (perlakuan kontrol) sebanyak 2.481,00 ml/ekor kemudian di ikuti berturut-turut oleh P2 (5 gr/liter) sebanyak 2.204,00 ml/ekor dan P1 (3 gr/ekor) sebanyak $1.757,00 \mathrm{ml} /$ ekor. Sedangkan konsumsi air minum tertinggi pada ayam broiler betina diperoleh pada P0 (perlakuan kontrol) sebanyak 2.167,00 ml/ekor di ikuti oleh P1 (3 gr/liter) sebanyak 2.158,75 ml/ekor dan P2 (5 gr/liter) sebanyak 2.151,00 ml/ekor.

Suhu lingkungan yang tinggi dalam pemeliharaan dapat menyebabkan ayam mengonsumsi air minum lebih banyak dibandingkan dengan konsumsi pakan hal ini sejalan dengan pendapat Qurniawan et al., (2016) bahwa apabila ayam pedaging mendapat cekaman panas maka ayam akan kesulitan membuang panas tubuhnya ke lingkungan. Kondisi ini mendorong ayam untuk banyak mengonsumsi air minum untuk menyeimbangkan kondisi panas dalam tubuhnya.

\section{Bobot Badan Akhir}

Berdasarkan hasil analisis menunjukkan bahwa perlakuan tidak berpengaruh nyata $(\mathrm{P}>0,05)$ terhadap bobot badan akhir pada ayam broiler jantan dan betina. Rata-rata bobot badan akhir pada ayam broiler jantan dan betina selama pemeliharaan dapat dilihat pada Tabel 3. 
Prosiding Seminar Nasional Pembangunan dan Pendidikan Vokasi Pertanian

Politeknik Pembangunan Pertanian Manokwari, 31 Juli 2021

e ISSN : 2774-1982

DOI : https://doi.org/10.47687/snppvp.v2i1.193

Tabel 3. Rataan bobot badan akhir ayam broiler jantan dan betina

\begin{tabular}{lccc}
\hline \multirow{2}{*}{ Kelompok } & \multicolumn{3}{c}{ Perlakuan } \\
\cline { 2 - 4 } & P0 $($ gr) & P1 $($ gr) & P2 (gr) \\
\hline Jantan & 941,70 & 842,60 & 950,60 \\
Betina & 867,50 & 668,60 & 851,40 \\
\hline
\end{tabular}

Berdasarkan Tabel 3 dapat dijelaskan bahwa Perolehan skor bobot badan akhir ayam broiler jantan lebih tinggi dibandingkan dengan ayam broiler betina yaitu terdapat pada level pemberian infusa P2 (5 gr/liter) sebanyak 950,60 gram/ekor di ikuti berturut-turut P0 (perlakuan kontrol) sebanyak 941,70 gram/ekor dan P1 (3 gr/liter) sebanyak 842,60 gram/ekor. Sedangkan bobot badan akhir ayam broiler betina tertinggi di peroleh pada $\mathrm{P0}$ (perlakuan kontrol) sebanyak 867,50 gram/ekor kemudian di ikuti oleh P2 (5 gr/liter) sebanyak 851,40 gr/ekor dan P1 (3 gr/liter) sebanyak 668,60 gr/ekor.

Widodo (2009) menyatakan bahwa pakan yang dikonsumsi oleh ternak unggas sangat menentukan pertambahan bobot badan sehingga berpengaruh terhadap efisiensi suatu usaha peternakan. Konsumsi pakan juga dipengaruhi oleh temperatur lingkungan, kesehatan ayam, perkandangan, wadah pakan, kandungan zat makanan dalam pakan dan stres yang terjadi pada ternak unggas tersebut. Hasil penelitian pada bobot badan ayam broiler yang diberikan infusa kulit kayu akway tidak memperbaiki serapan nutrisi pada ayam. Hal ini sesuai dengan pernyataan Uzer et al., (2013) bahwa pertambahan bobot badan sangat berkaitan dengan pakan, apabila konsumsi pakan terganggu maka akan mengganggu pertambahan bobot badan.

\section{Konversi Pakan}

Hasil analisis menunjukkan bahwa perlakuan infusa kulit kayu akway tidak berpengaruh nyata $(\mathrm{P}>0,05)$ terhadap konversi pakan pada ayam broiler jantan dan betina. Rata-rata konversi pakan pada ayam broiler jantan dan betina selama pemeliharaan dapat dilihat pada Tabel 4.

Tabel 4. Rataan konversi pakan ayam broiler jantan dan betina.

\begin{tabular}{lccc}
\hline \multirow{2}{*}{ Kelompok } & \multicolumn{3}{c}{ Perlakuan } \\
\cline { 2 - 4 } & P0 & P1 & P2 \\
\hline Jantan & 1,75 & 1,92 & 1,59 \\
Betina & 1,80 & 2,67 & 1,62 \\
\hline
\end{tabular}


Prosiding Seminar Nasional Pembangunan dan Pendidikan Vokasi Pertanian

Politeknik Pembangunan Pertanian Manokwari, 31 Juli 2021

e ISSN : 2774-1982

DOI : https://doi.org/10.47687/snppvp.v2i1.193

Berdasarkan Tabel 4 menunjukkan bahwa perlakuan infusa kulit kayu akway terhadap konversi pakan ayam broiler jantan dan betina tidak berpengaruh nyata $(\mathrm{P}>0,05)$. Rataan konversi pakan ayam terbaik terdapat pada ayam broiler jantan pada perlakuan infusa kulit kayu akway level P2 (5 gr/liter) sebanyak 1,59 kemudian di ikuti berturut-turut P0 (perlakuan kontrol) sebanyak 1,75 dan P1 (3 gr/liter) sebanyak 1,92. Pada ayam broiler betina konversi pakan terbaik terdapat pada perlakuan infusa kulit kayu akway pada level P2 (5 gr/liter) sebanyak 1,62 di ikuti berturut-turut P0 (perlakuan kontrol) sebanyak 1,80 dan P1 (3 gr/liter) sebanyak 2,67.

Fahrudin et al., (2016) menyatakan bahwa beberapa faktor utama yang mempengaruhi konversi pakan adalah genetik, kualitas pakan, penyakit, temperatur, sanitasi kandang, ventilasi, pengobatan dan manajemen kandang. Selain itu senyawa bioaktif yang terkandung dalam kulit kayu akway merupakan zat anti nutrisi pada pakan yaitu senyawa saponin dan tanin. Kandungan senyawa tanin dan saponin dapat mengikat protein dan dapat menghambat pertumbuhan unggas, menurunkan produksi telur (pada ayam petelur), menurunkan konsumsi ransum, dan juga menurunkan efisiensi penggunaan ransum. Senyawa tanin pada konsentrasi tinggi juga dapat menimbulkan efek toksik dan bahkan menyebabkan kematian pada ternak (Nahrowi, et al., 2019).

\section{Evaluasi Penyuluhan}

Tingkat pengetahuan peternak diukur dengan membandingkan nilai rata-rata pre-test dan post-test dengan menggunakan Uji-T berpasangan (paired t test). Pertanyaan untuk mengukur nilai tingkat pengetahuan berbentuk kuesioner sebanyak 10 soal dengan skor yang telah ditentukan. Paired t test adalah bagian dari analisis koperatif atau uji beda yang bertujuan untuk mengetahui adakah perbedaan rata-rata dari nilai pre-test dan post-test (Christie et al., 2018).

Hasil evaluasi penyuluhan tentang inovasi infusa kulit kayu akway pada performa ayam umur 3 - 4 minggu di kampung Warmomi distrik Manokwari Selatan. Pada pre-test responden mendapatkan nilai rata-rata 36,5 dan post-test mendapatkan nilai rata-rata 81,5. Hasil analisis uji t berpasangan (paired t test) menunjukkan bahwa pada pre-test dan posttest terdapat perbedaan sig 2 tailed $(0,00<0,05)$. Dari hasil analisis terdapat perbedaan maka dapat dikatakan bahwa terjadi peningkatan dalam proses penyuluhan dikarenakan materi, metode, media dan demonstrasi cara dapat dipahami oleh peternak selaku responden. 
Prosiding Seminar Nasional Pembangunan dan Pendidikan Vokasi Pertanian

Politeknik Pembangunan Pertanian Manokwari, 31 Juli 2021

e ISSN : 2774-1982

DOI : https://doi.org/10.47687/snppvp.v2i1.193

\section{KESIMPULAN DAN SARAN}

Berdasarkan Hasil analisis data penelitian infusa kulit kayu akway dengan level pemberian yang berbeda tidak berpengaruh nyata $(\mathrm{P}>0,05)$ pada konsumsi pakan, konsumsi air minum, bobot badan akhir dan konversi pakan. Hasil analisis data penyuluhan menggunakan analisis uji paired t-test menunjukkan bahwa terdapat perbedaan antara tes awal dan tes akhir. Hal ini menjelaskan bahwa terdapat peningkatan pengetahuan peternak setelah dilakukan penyuluhan, dikarenakan materi, metode, media dan demonstrasi cara dapat dipahami oleh peternak selaku responden penyuluhan serta materi penyuluhan merupakan inovasi baru dan menarik bagi peternak.

Pembuatan infusa kulit kayu akway merupakan inovasi baru di bidang peternakan dengan memanfaatkan bahan herbal dari potensi lokal yaitu tanaman kayu akway dengan kandungan bioaktif yang dipercaya oleh penduduk asli Pegunungan Arfak sebagai tanaman obat. Penulis menyarankan pada penelitian lebih lanjut dapat menentukan parameter terkait dengan kesehatan pada ternak. Dengan memperhatikan metode penelitian terkait dosis/level pemberian infusa kulit kayu akway dengan memperbanyak jumlah perlakuan dan ulangan, sehingga data yang diperoleh bervariasi dan mendapatkan hasil yang lebih baik.

\section{UCAPAN TERIMA KASIH}

Ucapan terima kasih penulis sampaikan kepada kedua dosen pembimbing, dosen konsultan, dosen peguji dan kepada kelompok tani kujubi yang telah membantu dalam penelitian dan penyusunan tugas akhir.

\section{DAFTAR PUSTAKA}

Badan Pengawas Obat dan Makanan RI. (2011). Acuan Sediaan Herbal. Volume ke 6 Edisi 1. Jakarta.

Cepeda G., N., Lisangan, M., M., Roreng, K., M., Permatasari, I., E., Manalu, C., D., \& Tainlain, W. (2018). Aktivitas penangkalan radikal bebas dan kemampuan reduksi ekstrak kulit kayu akway (Dyrmis piperita Hook. F.). Jurnal Aplikasi Teknologi Pangan. 7 (4): 168-173.

Christie, E.J.C. Montolalu, Yohanes, \& A.R. Langi. (2018). Pengaruh Pelatihan Dasar Komputer Dan Teknologi Informasi Bagi Guru-Guru Dengan Uji-T Berpasangan (Paired Sample T Test). Jurnal Matematika dan Aplikasi deCartesiaN, 7(1): 44 46.

Dalimartha, S. (2014). Tumbuhan Sakti Atasi Asam Urat. Jakarta: Penebar Swadaya. 
Prosiding Seminar Nasional Pembangunan dan Pendidikan Vokasi Pertanian

Politeknik Pembangunan Pertanian Manokwari, 31 Juli 2021

e ISSN : 2774-1982

DOI : https://doi.org/10.47687/snppvp.v2i1.193

Fahrudin A, Tanwiriah W, \& Indrijani, H. (2016). Konsumsi Ransum, Pertambahan Bobot Badan dan Konversi Ransum Ayam Lokal di Jimmy's Farm. Cipanas Kabupaten Cianjur.

Fati, N., Siregar, R., \& Luthfi. M.U. (2019). Pengaruh Pemberian Infusa Daun BangunBangun (Coleus amboinicus, Lour) Terhadap Performa Broiler. Journal of Livestock Ana Animal Health, 2(1), 05-09.

Nahrowi, Laconi, E. B., Ridla, M. \& Jayanegara, A. (2019). Komponen Antinutrisi Pada Pakan. IPB Press. Bogor.

Qurniawan, A., Arief, I.I., \& Afnan, R. (2016). Performans Produksi Ayam Pedaging pada Lingkungan Pemeliharaan dengan Ketinggian yang Berbeda di Sulawesi Selatan. Jurnal Veteriner. 17(4): 622-633.

Rasyaf, M. (2008). Panduan Beternak Ayam Pedaging. Penebar Swadaya. Jakarta.

Saputra, W. Y., L. D. Mahfudz \& N. Suthama. (2013). Pemberian Pakan Single Step Down Dengan Penambahan Asam Sitrat Sebagai Acidifier Terhadap Performa Pertumbuhan Broiler. Animal Agriculture Journal.

Syakir, M., Bermawie, N., Agusta, H., \& Paisey, E.N. (2011). Karakterisasi Sifat Morfologi dan Penyebaran Kayu Akway (Drimys sp.) di Papua Barat. Jurnal Penelitian Tanaman Industri, 17(4): 169-173.

Uzer, F. Irianti, N. \& Roesdiyanto. (2013). Penggunaan Pakan Fungsional dalam Ransum Terhadap konsumsi Pakan dan Pertambahan Bobot Badab Ayam Broiler. Jurnal Ilmiah Petenakan, 1(1): 282-288.

Widodo, W. (2009). Perbandingan Performans Dua Strain Broiler Yang Mengonsumsi Air Kunyit. Jurnal Ilmiah Ilmu-ilmu Peternakan, 13: 146-152. 